Article

\title{
Director Opinion on Community Competence: Evidence from Management Organizations of the Rural Community Support Project in South Korea
}

\author{
Seongjun Eom * (1), Shinho Rhee, Hyunjun Kim and Myeonghwan Kim \\ Department of Agricultural and Rural Engineering, Chungbuk National University, Chungdea-ro 1, Seowon-Gu, \\ Cheongju, Chungbuk 26844, Korea; rhee2574@cbnu.ac.kr (S.R.); grasia84@naver.com (H.K.); \\ mhkim3306@cbnu.ac.kr (M.K.) \\ * Correspondence: nice2002@cbnu.ac.kr; Tel.: +82-10-3440-3293; Fax: +82-504-199-3293
}

Received: 8 March 2020; Accepted: 25 May 2020; Published: 3 June 2020

check for updates

\begin{abstract}
In Korea, there are very few successful cases of Rural Community Support Project management organizations, including the economic (income) part as well as the community revitalization part and the facility operation management part. To counter these problems, competence diagnostic results can assist in building these management organizations' competences. Previously, studies have been conducted on the diagnosis of an individual's competence. This study, however, was conducted to develop a tool for such a diagnosis using survey items derived through literature review and by verifying the adequacy of this content. The surveys were then finalized by further verifying the construction validity and reliability of the questionnaires. The surveys were administered to the chairs and the directors of Rural Experience Recreational Village councils, to develop an organizational diagnostic tool for the competent operational management of rural communities. The diagnostic tool developed by this study can be used as an indicator to determine whether a rural village has the capacity to carry out projects.
\end{abstract}

Keywords: management organization competence; rural community support project; competence diagnosis tools; director opinion

\section{Introduction}

Nationally, investment in Korea since the 1970s has focused on cities in the process of rapid growth. This has increased the gaps in income and quality of life between rural and urban areas. The opening up of agricultural markets after the Uruguay Round also weakened agricultural competitiveness. The resulting urbanization of young people caused a rapid decrease in the population and the aging of rural areas. Accordingly, the central government implemented policies aiming to increase agricultural competitiveness and improve quality of life in rural areas. Although these aims were achieved, the population continued to decrease and the areas continued to age [1]. There is an increasing awareness that regional development requires an impetus to address the problems of rural hollowing. (Rural hollowing is the neglect, vacancy, and subsequent abandonment of rural dwellings) This requires the activation of the rural community so that the residents can participate in solving their communities' problems and improve their quality of life [1].

Community development requires partnerships to solve local problems and to build strength, self-sufficiency, and well-being. In the face of globalization and economic competition, communities are increasingly at the mercy of large economic systems, over which they have little or no control [2]. Accordingly, the South Korean government's Ministry of Agriculture, Food and Rural Affairs carried out the Rural Community Support Project (RCSP) through various regional development projects. The 
RCSP is based on the "resident participatory village development project" that began after persistent change and integrations in the 2000s [3]. The project extends mostly to villages and is conducted using a bottom-up approach led by members of the community, emphasizing the competence and participation of members [3] and recognizing the rural residents' associations as major participants in all phases of the project.

As of 2015, there are over 2000 rural communities that have completed, or are carrying out, the RCSP, most of which are in the management phase following project completion. The rural residents' organizations, which were established to ensure the smooth operation of each rural community's projects, have become the organizations in charge of managing the facilities and programs developed through the RCSP. However, many of the facilities and programs have been neglected and improperly managed following the project, due to the failures of these management organizations [4]. There is a need for measures that prevent the neglect of the facilities and programs developed by the RCSP and that sustainably improve the competence of the management organizations. Therefore, the factors that determine competence must be determined, and diagnostic tools that include those factors must be further developed through research. The rural residents' organizations, formed through the RCSP, are developed through the phases of formation, growth, and continuous maintenance [5].

An RCSP management organization is led by members who have worked together since the initial phase of the project's promotion until its implementation. The organization will have passed the formation phase, during which their leaders would have been greatly influential, and will be in the growth or maintenance phase. Community competence, including that of rural communities, involves individuals as well as social agents, such as third-party organizations and networks [6]. The relevant competencies can be categorized into individual, organizational, and network competences $[7,8]$. However, the competence diagnostic indices and tools used in previous studies were developed for individuals, which complicates organizational diagnosis. Additionally, previous studies used unstructured component lists, lacked component verification, and had limited tools at their disposal.

Previous diagnostic tool development was limited to the level of individuals because the survey questionnaires mostly used "I" in reference to the respondents. In this case, the problem is the tendency for only the influence of individual residents to be measured, begging the question as to whether the sum of the individual competences is the same as the total community's competence. The diagnostic tools developed in preceding studies were also underutilized, due to problems such as the simplicity of the components for diagnosis, which limited their scope and lacked verification. Therefore, in order to improve their use, tools for systematically measuring competence should be organized via sufficient theoretical review and analyses during the development process. This will allow the data from the systematic surveys and the subsequent competence diagnoses to be used to improve the efficacy of education and consultation in building competences. Based on these issues, this study aims to develop a diagnostic tool for determining competence by constructing an organized social entity as the subject of diagnosis and conducting a corresponding theoretical review and analysis.

The details of this study are organized as follows: Section 2 reviews literature regarding the components of community capability; Section 3 explains the RCSP; Section 4 analyzes relevant expert opinions; Sections 5 and 6 explain the data and methodology behind the study; and Section 7 presents the study results, before discussing the conclusions.

\section{Components of Community Competence}

Discussions regarding the components that might comprise community competence began in the 1990s, in order to inform specific approaches and solutions to pending community problems. It was framed that modernizing the political process facilitates the continuity of communities, and, therefore, the significance of the political process is in its service to communities facing a crisis by building up their capacity to solve problems. This includes increasing competences in "introspection", "participation", and "integration". 
Healey (1997) claims that collaborative planning is required to address pending community issues. With the rapidly changing environments and multiple competing variables in contemporary society, institutional capacity, or institutional capital, constitutes the capacity for consensus among community members. This capital consists of an institute's knowledge and relational resources, and its capacity for mobilization. The generation of institutional capital leads to empowerment [9].

Chaskin (2001); Chan, Lam and Cheng (2009); and Stenning (2013) provide a relational framework between community capability and empowerment. Their projects identify the characteristics of community capability, including "sense of community", "level of commitment", "problem-solving ability", and "access to resources" [6,10,11]. Laverack (2001); Chan, Lam and Cheng (2009); and Islam (2014) propose that community competence constitutes nine components, based on the ability for communities to perform the following: improve stakeholder participation; develop local leadership; build empowering organizational structures; increase assessment capabilities; improve resource mobilization; enhance the ability to question decisions; "strengthening links to other organizations and people" [10,12,13]; increase insight into program management; and create an equitable relationship with outside agents [10].

Sim (2004) defined "introspection competence" as the ability of subjects to critically evaluate themselves and their environment, "participation competence" as the ability of the subjects to participate in organized community activities, and "integration competence" as the ability of the subjects to form and reinforce connections among themselves [14]. Kang (2007) proposes that community competence comprises eight components: "perception of regional problems," "circumstances of regional problems," "local leadership," "community participation," "resource mobilization," "empowering organizational structures," "connections to others", and "control of regional policies" [15]. Kim, Chun, Seo, and Yun (2008) propose that "trust," "participation", and "network" form the components of social capital as a community competence [16].

Shin (2012) proposes that community competence consists of the "individual competence" that enables residents to voluntarily participate in community activities; "participation competence" is defined as the various activities and circumstances at an organizational, group, or regional level; and "relational competence" is associated with social interaction and communication at an individual level [7].

Yeo, Park, and Kim (2015) propose that "individual competence," "organizational competence," and "network competence" are the components of community competence. Their study also proposes that individual competence is enhanced hierarchically. Firstly, enhancements of competence occur in the perception of a region, its ability to actively solve regional problems, and by the establishment of local leadership. Secondly, enhancements of organizational competence occur by the establishment of the groundwork for participation, and in organizational building. Thirdly, network competences are enhanced by the formation of ties amongst residents, the expansion of connections, and the establishment of networks throughout the competence development stages of perception, process, and outcome [8].

The components of community competence organizational capacity, as defined by the above studies, are shown in Table 1. 
Table 1. The components of community competence 3. Rural Community Support Project (RCSP).

\begin{tabular}{|c|c|c|c|c|}
\hline Researchers & \multicolumn{3}{|c|}{ Component } & Type \\
\hline $\begin{array}{l}\text { Jänicke (1997); } \\
\text { Sim (2004) }\end{array}$ & \multicolumn{2}{|c|}{ Participation capacity $[14,17]$} & $\begin{array}{c}\text { Participation type, } \\
\text { participation awareness } \\
{[14,17]}\end{array}$ & (2) \\
\hline $\begin{array}{c}\text { Healey (1998); } \\
\text { Kim and Lee (2014) }\end{array}$ & \multicolumn{2}{|c|}{ Mobilization capacity $[9,18]$} & $\begin{array}{c}\text { Participant interaction, } \\
\text { social learning process, } \\
\text { consensus building process } \\
{[9,18]}\end{array}$ & (1) \\
\hline Chaskin (2001) & \multicolumn{3}{|c|}{ Community commitment [6] } & (2) \\
\hline \multirow{3}{*}{$\begin{array}{l}\text { Laverack (2001); } \\
\quad \text { Kang (2007) }\end{array}$} & \multicolumn{3}{|c|}{ Community participation $[12,15]$} & (2) \\
\hline & \multicolumn{3}{|c|}{ Resource mobilization $[12,15]$} & (1) \\
\hline & \multicolumn{3}{|c|}{ Empowering organization building $[12,15]$} & (3) \\
\hline $\begin{array}{l}\text { Kim, Chun, Seo, and Yun } \\
\text { (2008) }\end{array}$ & \multicolumn{2}{|c|}{ Participation [16] } & $\begin{array}{l}\text { Social participation, public } \\
\text { participation [16] }\end{array}$ & (2) \\
\hline \multirow{6}{*}{ Shin (2012) } & \multirow{6}{*}{$\begin{array}{l}\text { Participation } \\
\text { capacity }[7]\end{array}$} & $\begin{array}{c}\text { Participation } \\
\text { consciousness/activity } \\
{[7]}\end{array}$ & $\begin{array}{l}\text { Political participation, social } \\
\text { participation, economic } \\
\text { participation [7] }\end{array}$ & (3) \\
\hline & & \multirow[t]{2}{*}{$\begin{array}{l}\text { Participation } \\
\text { environment/base [7] }\end{array}$} & $\begin{array}{c}\text { Participation } \\
\text { environment/structure, } \\
\text { Participation base/support } \\
{[7]} \\
\end{array}$ & (4) \\
\hline & & & Participation cooperation [7] & (2) \\
\hline & & \multirow{3}{*}{$\begin{array}{c}\text { Participation } \\
\text { process/performance [7] }\end{array}$} & Mobilization capacity [7] & (3) \\
\hline & & & Collective efficacy [7] & (2) \\
\hline & & & $\begin{array}{l}\text { Participation organization } \\
\text { characteristics [7] }\end{array}$ & (2) \\
\hline \multirow[t]{2}{*}{ Yeo et al. (2015) } & \multirow[t]{2}{*}{$\begin{array}{l}\text { Organizational } \\
\text { capacity }[8]\end{array}$} & \multicolumn{2}{|c|}{$\begin{array}{l}\text { Participation form change, establishing a foundation for } \\
\text { participation [8] }\end{array}$} & (4) \\
\hline & & \multicolumn{2}{|c|}{ Organization structure [8] } & (4) \\
\hline \multicolumn{5}{|c|}{$\begin{array}{c}\text { Reference of competences: | Type (1) Resource-mobilization | Type (2) Participatory environment creation | Type (3) } \\
\text { Organization building | }\end{array}$} \\
\hline
\end{tabular}

\subsection{Community Participatory Development}

Korea's rural area development policy introduced the "Community Development Project" - developed by the United Nations-in the late 1950s; the "Pilot Rural Construction Project" in the 1960s, and "The Saemaul Undong" or "New Village Movement" in the 1970s. In the 1980s, "Comprehensive Rural Development" was introduced; the "Development of Residential Areas" followed in the 1990s; the 2000s saw the "Development of Complex Living Spaces and Quality of Life"; and "Integrated Rural Development" was introduced in the 2010s.

Excessive emphasis was placed on the physical readjustment of infrastructure in the 2000s. Other problems also arose, such as the Korean government's top-down administrative approach to projects, and the need for changes in rural development policies. To counter these issues, new projects were implemented, such as the "Reclamation Project" by the Ministry of Government Administration and Home Affairs, the Ministry of Agriculture and Forestry's green "Rural Experience Village" project in 2002, and the Ministry's "Rural Township Project" in 2004. The characteristics of each project were that, firstly, they contributed to spatial development; secondly, the projects used a bottom-up administrative approach with a voluntary participation system that was open to the public; and, thirdly, they emphasized community competence and participation. The bottom-up approach began to be recognized as a necessary measure of success during the promotion, planning, implementation, and maintenance phases of a project.

Projects that started in the 2000s are collectively referred to as "Community Participatory Development Projects". These led to amendments to the Korean government's budgetary regulations, changes of name due to alterations in policy, project integration, and the development of new community support projects. 


\subsection{Agricultural Policies Targeting Rural Communities}

The opening-up of the agricultural market expanded externally after the Uruguay Round in Korea, and the strengthening of agricultural competitiveness became the primary objective of agricultural policy. Scale and specialization were achieved through large-scale investment and loan projects in the agricultural sector. This resulted in an improvement in the overall efficiency of the agricultural system. However, the agricultural economy remained weak compared to that of other sectors; polarization occurred, and the burden on agricultural policy increased as foreign interest in the sector grew. The Korean government consequently realized the positive effects that agricultural efficiency and a community's voluntary capacity have on the happiness of residents and, therefore, set these as agricultural policy objectives. The object, contents, and methods of agricultural policy changed as follows [1].

Firstly, the targets of policy changed from individual management entities to rural communities. The aging and depopulation of rural areas continued, and the emergence of new types of sixth industrialization (The six industrialization means activities to promote the revitalization of the local economy by creating new added value and local jobs through the convergence of secondary industries (manufacturing, processing) and service tertiary industries ((experience, tourism, etc.)) utilizing tangible and intangible resources in rural areas ((http://wwww.6thindustry.com)) inevitably expanded the scope of policy targets. Agricultural policies that targeted rural communities, promoted their revitalization and networkization, and encouraged the independence of individual management entities were implemented.

Secondly, the contents of the policies changed from individual approaches to sector approaches and to the combination of production with the sixth industrialization of agriculture. Developments in information communication technology and biotechnology facilitated the integration of different industries and were used in the development of agricultural and rural areas. This resulted in policy changes to support sixth industrialization, whereby industries (production, processing, tourism, etc.) were organically coupled-mainly in rural communities.

Thirdly, policies changed to a bottom-up approach, whereby communities and residents participated and bore the responsibility for government-led, top-down initiatives. The differences between and various capacities of individual management bodies and rural communities are recognized as a factor influencing agricultural competitiveness. Therefore, an upward approach to policies that reflects local characteristics and voluntary participation has been adopted, where the responsibility lies with the farmers, municipalities, and rural communities.

\section{Expert Opinion}

The three questions for the research required to develop a tool that can diagnose the competence of RCSP management organizations are "Based on previous literature, what is the summary of components required for competence diagnosis?", "What are the components of diagnosing competence, as verified by expert opinion?", and "Is the diagnosis tool that has been developed, based on expert verification, valid for diagnosing the competence of RCSP management organizations?". To find answers to these questions, this study was conducted by developing preliminary competence diagnosis components and then verifying these via surveys conducted with experts and the residents of rural villages. The first step of the research was to propose subfactors for each component of competence. Next, competence measurements for each subfactor were compiled. The preliminary diagnosis components were then developed based on these measurements. The component contents were verified through expert surveys, and, thereafter, their construct validity and reliability were verified through surveys with rural residents.

Four criteria were proposed to develop the subfactors of each component of community organization competence. These were, firstly, to integrate the components if their names and measurement items were the same; secondly, to maintain components with different measurement items, even if the name was the same; thirdly, to exclude components with select items that were 
difficult to quantify by the results of diagnosis; and, fourthly, to retain detailed components that did not apply to the aforementioned criteria. The criteria enabled the subfactors of previous studies to be combined according to three community organization competences: resource-mobilization, creating an environment conducive to community participation, and organization-building. Five criteria were then used to propose the competence measurements for each subfactor proposed by previous studies, and these items were then processed as per the previous components. Firstly, the measurement item descriptions were revised according to the research objective, which was the development of a competence diagnosis tool for rural community organizations established to manage the projects supported by central government at the village level. Secondly, measurement items in subfactors with the same meaning were combined. Thirdly, measurement items that did not apply to the two prior criteria were retained. Fourthly, should the researcher have deemed it necessary, additional items were included. Finally, this study did not use frequency as a selection criterion for measurement, as used by previous studies, due to the lack of measurement items with a frequency of $<2$. With reference to the measurement items for each subfactor as presented by previous studies, this study proposes the preliminary components for diagnosing the competence of RCSP management organizations.

To verify the validity of the contents of the preliminary components, developed based on meta-analysis, a survey with experts from administrative agencies-working or involved in research with the RCSP, intermediate support organizations, rural development consulting firms, universities, and research institutes were conducted. The selection was primarily based on the respondents' claims to understand the nature of the research, due to their interactions with operational management organization members.

For the finalization of the competence components and the development of the diagnostic tool, this study conducted surveys with the leaders of Rural Experience Villages nationwide. The survey verified the construct validity and the reliability of the preliminary components with validated content. Councils for Rural Experience Recreational Villages were selected as the management organizations for analysis. Many of the villages that carried out the RCSP were designated as licensed Rural Experience Villages. Councils were formed that are still operated by community participants, which deemed them appropriate organizations for this survey's purposes. The survey was conducted with the chairpersons and managers of the councils, as they are the organizations' leaders and are thus highly aware of the competences of the organizations to which they belong.

\section{Data}

In order to verify the construct validity and reliability of the preliminary questionnaire-of which the content validity had been verified-573 questionnaires were distributed via e-mail, and 118 face-to-face interviews were conducted with experts (chairmen or managers of the village councils), from August 2007 to 22 September 2017. Of the distributed questionnaires, 47 e-mail responses (a recovery rate of $7.9 \%$ ) and 118 face-to-face inquiries were recovered (a recovery rate of $100 \%$ ). The total survey resulted in 158 valid responses (an effective data rate of $95.8 \%$ ), excluding seven fraudulent responses to the questionnaire, out of the 165 responses received. The general demographics of participants are presented in Table 2. 
Table 2. The general demographics of respondents to the construct and reliability validity survey.

\begin{tabular}{|c|c|c|c|}
\hline \multicolumn{2}{|c|}{ Classification } & Frequency & Percentage \\
\hline \multirow{3}{*}{ Gender } & Male & 75 & 47.5 \\
\hline & Female & 83 & 52.5 \\
\hline & Total & 158 & 100.0 \\
\hline \multirow{5}{*}{ Age } & Under 45 years & 39 & 24.7 \\
\hline & Under $45-55$ years & 66 & 41.8 \\
\hline & Under 55-65 years & 44 & 27.8 \\
\hline & More than 65 years & 9 & 5.7 \\
\hline & Total & 158 & 100.0 \\
\hline \multirow{3}{*}{ Position } & Chairman & 34 & 21.5 \\
\hline & Manager & 124 & 78.5 \\
\hline & Total & 158 & 100.0 \\
\hline \multirow{10}{*}{ Region } & Gyeonggi-Do (province) & 11 & 7.0 \\
\hline & Gangwon-Do & 12 & 7.6 \\
\hline & Chungcheongbuk-Do & 19 & 12.0 \\
\hline & Chungchengnam-Do & 9 & 5.7 \\
\hline & Jeollabuk-Do & 28 & 17.7 \\
\hline & Jeollanam-Do & 11 & 7.0 \\
\hline & Gyeongsangbuk-Do & 31 & 19.6 \\
\hline & Gyeongsannam-Do & 35 & 22.2 \\
\hline & Jeju-Island & 2 & 1.3 \\
\hline & Total & 158 & 100.0 \\
\hline
\end{tabular}

\section{Methodology}

The results of the expert survey were analyzed in the following order. Firstly, the number of experts that selected preliminary items as valid was calculated through frequency analysis. Then, the following formula was used to calculate the content validity of each item, with the validity or invalidity of items for competence diagnosis being based on the mean:

$$
C Q(\%)=(N E \div N P E) \times 100
$$

where $C Q=$ content validity by question, $N E=$ the number of experts selected as valid respondents, and $N P E=$ the number of participating experts.

The survey results for rural residents were analyzed first, using Window SPSS 24 for the factor and reliability analyses.

Factor analyses were conducted to verify the construct validity of the preliminary components with previously verified content validity. Factor analysis is most commonly used as a statistical verification method, and these analyses confirmed whether the survey items adequately measured the factors of the items in the operational definition [19]. Prior to the factor analysis, the Kaiser Mayer Olkin (KMO) test and Bartlett's test of sphericity were performed to assess the suitability of the data. The KMO test for sampling adequacy, a popular diagnostic measure, tested if the partial correlations between the variables were weak [20] and as a measure of the variables' homogeneity [21]. The value of the $\mathrm{KMO}$ is that it thoroughly tests the adequacy of the sampling, as well as measuring the sampling adequacy for each variable. 
If the value of Bartlett's test of sphericity satisfies $p<0.05$ and the KMO value is greater than 0.5 , the data are deemed suitable for factor analysis [22]. Principal axis factoring was used for the factor extraction, and the adequacy of the number of factors was reviewed, considering Kaiser's rule that the eigenvalue of one factor must be at least 1.0. The factors were then rotated, using direct oblimin for the oblique rotation method, and items were deleted by applying the following criteria. Firstly, if a factor's loading was at least 0.3 in direct oblimin rotation, it was considered to be related to the relevant factor $[19,22]$. Secondly, because the intention of the analysis was to verify construct validity, items that did not fall within the summarized components of community organization competence from the literature review were eliminated. Thirdly, the extraction of each factor must be based on at least three variables for meaningful interpretation [23], thereby eliminating items that did not meet this criterion.

To verify the reliability of the diagnostic tool, which consists of the preliminary components with verified construct validity, reliability analyses were conducted on all current and important level results for each competence component's constituting items and summarized according to the factor analyses. This was verified using Cronbach's alpha. Cronbach's alpha has been described as one of the most important and widely-used statistics for research that involves test construction, and it is routinely used in research with multiple item measurements [24,25]. The data are considered reliable if Cronbach's alpha is at least 0.6 in exploratory research, 0.8 in basic research, and 0.9 in applied research [26]. This study is exploratory research and, therefore, the standard is set at 0.6 or higher. This study has verified that no eliminated item had a greater Cronbach's alpha than those selected.

\section{Findings}

The following table shows the results of the construct validity verification for the 19 preliminary components of competence diagnosis, which had their content validity verified through the rural resident survey. The KMO value was 0.907 , and the Bartlett's test of sphericity value was 1526.824 $(p<0.001)$, proving that the data were suitable for analysis. As a result of the factor analyses, the four factors with an eigenvalue of at least 1.0, and which explained $63.104 \%$ of the total variance, were eliminated. Among the items developed to measure the resource-mobilizing competence of organizations, Q1, Q5, and Q15 were found to be more related to the competence of the creation of a participatory environment and were eliminated. Q6 and Q7 were also developed to measure resource-mobilizing competence but were found to construct separate factors. These were eliminated considering the various interpretations for the extraction of a factor based on at least three other factors. After excluding these five items and reviewing the suitability of data, the KMO value was 0.905 and the Bartlett's test of sphericity value was $1080.027(p<0.001)$, thus showing them to be suitable for factor analysis. As a result of the analyses, three factors that had an eigenvalue of at least 1.0, and which explained $63.736 \%$ of the total variance, were extracted. Only five items of resource-mobilizing competence were eliminated, which made the change of the factor's name to "consensus-forming competence" inevitable, based on reexamination (Table 3). 
Table 3. The results of verifying the validity of the preliminary component constructs.

\begin{tabular}{|c|c|c|c|c|}
\hline \multirow{2}{*}{$\begin{array}{l}\text { Question Number } \\
\text { (Capacity Element) }\end{array}$} & \multicolumn{3}{|c|}{ Factor (Name) } & \multirow[t]{2}{*}{ Commonality } \\
\hline & $\begin{array}{l}\text { Factor } 1 \text { (Creating } \\
\text { a Participatory } \\
\text { Environment) }\end{array}$ & $\begin{array}{c}\text { Factor } 2 \\
\text { (Forming a Consensus) }\end{array}$ & $\begin{array}{c}\text { Factor } 3 \\
\text { (Organization Building) }\end{array}$ & \\
\hline $\begin{array}{l}\text { Q17 (participation of rural residents } \\
\text { in the project) }\end{array}$ & 0.734 & 0.057 & 0.043 & 0.635 \\
\hline Q20 (social participation) & 0.724 & -0.045 & -0.031 & 0.464 \\
\hline $\begin{array}{l}\text { Q16 (organization members' } \\
\text { participation in the project) }\end{array}$ & 0.583 & 0.065 & 0.108 & 0.490 \\
\hline Q22 (economic participation) & 0.575 & 0.050 & 0.086 & 0.442 \\
\hline $\begin{array}{l}\text { Q24 (atmosphere encouraging } \\
\text { residents from other villages to } \\
\text { participate in village affairs) }\end{array}$ & 0.505 & 0.143 & 0.104 & 0.454 \\
\hline $\begin{array}{l}\text { Q3 (ability to mediate conflicts } \\
\text { between organization members) }\end{array}$ & -0.415 & 0.690 & 0.095 & 0.458 \\
\hline $\begin{array}{l}\text { Q13 (awareness of organization } \\
\text { members about pending } \\
\text { community issues) }\end{array}$ & 0.222 & 0.682 & -0.116 & 0.565 \\
\hline $\begin{array}{l}\text { Q8 (decision making structure } \\
\text { between organization members) }\end{array}$ & 0.054 & 0.642 & -0.026 & 0.433 \\
\hline $\begin{array}{l}\text { Q10 (reflection of the opinions of } \\
\text { rural residents) }\end{array}$ & 0.086 & 0.588 & 0.185 & 0.598 \\
\hline $\begin{array}{l}\text { Q9 (consultation opportunities for } \\
\text { organization members and } \\
\text { rural residents) }\end{array}$ & 0.161 & 0.498 & 0.124 & 0.481 \\
\hline $\begin{array}{l}\text { Q31(activation of other organizations } \\
\text { in the village) }\end{array}$ & 0.115 & -0.105 & 0.783 & 0.640 \\
\hline $\begin{array}{l}\text { Q29 (cooperation of other } \\
\text { organizations in the village) }\end{array}$ & -0.054 & 0.144 & 0.765 & 0.682 \\
\hline $\begin{array}{l}\text { Q27 (formation of community culture } \\
\text { through the project) }\end{array}$ & 0.171 & -0.021 & 0.738 & 0.717 \\
\hline $\begin{array}{l}\text { Q28 (the project's contribution and } \\
\text { role in resolving pending } \\
\text { community issues) }\end{array}$ & -0.025 & 0.083 & 0.672 & 0.503 \\
\hline Eigenvalue & 6.569 & 1.279 & 1.075 & \\
\hline Explained variance (\%) & 46.920 & 9.134 & 7.682 & \\
\hline Cumulative variance (\%) & 46.920 & 56.054 & 63.736 & \\
\hline $\mathrm{KMO}$ & & & & 0.905 \\
\hline \multirow[t]{2}{*}{ Bartlett's test of sphericity } & $x^{2}$ & & & 1080.027 \\
\hline & df ( $p$-value) & & & $91(.000)$ \\
\hline
\end{tabular}

The diagnosis tool consists of 14 items with verified content and construct validity. All items had to have a Cronbach's alpha of at least 0.6 , the reference value. There was no case in which the Cronbach's alpha turned out to be greater than that of an item when eliminated, thereby proving that the tool and corresponding 14 items are reliable (Table 4). 
Table 4. Reliability analysis.

\begin{tabular}{|c|c|c|c|c|c|}
\hline \multirow{3}{*}{ Classification } & \multirow{3}{*}{$\begin{array}{l}\text { Question } \\
\text { Number }\end{array}$} & \multicolumn{4}{|c|}{ Cronbach's Alpha } \\
\hline & & \multicolumn{2}{|c|}{ Current Level } & \multicolumn{2}{|c|}{ Important Level } \\
\hline & & Total & $\begin{array}{l}\text { When } \\
\text { Eliminated }\end{array}$ & Total & $\begin{array}{l}\text { When } \\
\text { Eliminated }\end{array}$ \\
\hline \multirow{5}{*}{ Consensus-forming competence } & Q3 & \multirow{5}{*}{0.820} & 0.798 & \multirow{5}{*}{0.807} & 0.802 \\
\hline & Q8 & & 0.796 & & 0.759 \\
\hline & Q9 & & 0.784 & & 0.724 \\
\hline & Q10 & & 0.771 & & 0.756 \\
\hline & Q13 & & 0.777 & & 0.782 \\
\hline \multirow{5}{*}{$\begin{array}{l}\text { Participatory } \\
\text { environment-creating competence }\end{array}$} & Q16 & \multirow{5}{*}{0.825} & 0.791 & \multirow{5}{*}{0.838} & 0.791 \\
\hline & Q17 & & 0.768 & & 0.795 \\
\hline & Q20 & & 0.796 & & 0.798 \\
\hline & Q22 & & 0.799 & & 0.812 \\
\hline & Q24 & & 0.800 & & 0.832 \\
\hline \multirow{4}{*}{$\begin{array}{l}\text { Organization-building } \\
\text { competence }\end{array}$} & Q27 & \multirow{4}{*}{0.865} & 0.810 & \multirow{4}{*}{0.822} & 0.758 \\
\hline & Q28 & & 0.858 & & 0.793 \\
\hline & Q29 & & 0.821 & & 0.764 \\
\hline & Q31 & & 0.823 & & 0.785 \\
\hline
\end{tabular}

Facilities and programs are not properly operated and managed after a project due to a lack of management organization competence. To address this problem, the competences of management organizations need to be enhanced based on the results of the competence diagnosis. Previous studies have inadequately progressed the development of competence diagnosis tools for RCSP management organizations. Accordingly, this study was conducted to develop a diagnosis tool, which, after verifying content validity, construct validity, and reliability, is as follows.

\section{Conclusions}

In South Korea, due to a lack of capacity on the part of management organizations, facility and program operations have not been properly managed since the government completed its rural community support project. To counter this problem, an organization's capacity must be built according to the results of its competence diagnosis. However, the tools required to diagnose the competence of Rural Community Support Project management organizations have not been sufficiently developed by previous studies. Accordingly, the purpose of this research was to develop a tool that diagnoses the capabilities of Rural Community Support Project management organizations, and the results of this development, according to expert opinion, are as follows.

The competence diagnosis showed that verifying the ability of management organizations to operate and manage the project, and developing competences for independence forming a consensus among rural residents and organization members, was rated as more important than the ability to utilize village resources.

The competences of RCSP management organizations consist of (1) "consensus-forming competence", which is the ability to operate and manage the project via agreement between community members; (2) "participatory environment-creating competence", which is the ability to create an environment that leads to the involvement of the community in activities; and (3) "organization-building competence", which is the ability to build a sustainable, resident-led organization through productive community activity and the formation of cooperative relationships with other organizations.

Consensus-forming competence includes five elements. These are the "ability to mediate conflicts between organization members", "decision-making structure of organization members", "consultation opportunity for organization members and rural residents", "reflection of opinions of rural residents", and "awareness of organization members about pending community issues". Participatory environment-creating competence includes the elements of the "participation of organization's members 
in the project", the "participation of rural residents in the project", "social participation", "economic participation", and an "atmosphere encouraging residents from other villages to participate in village affairs". Organization-building competence includes four elements, which are "the formation of community culture through the project", "the project's contribution and role in resolving pending community issues", "cooperation with other organizations in the village", and the "activation of other organizations in the village."

The diagnosis tool developed in this study was verified based on the results of a survey conducted with RCSP experts and the leaders of RCSP management organizations. Therefore, it differentiates itself from the competence diagnosis tools developed by previous studies because it considers "rural areas" as the region and "management organizations" as the subject for diagnosis. Additionally, the diagnosis results obtained using the tool developed by this study allow competence enhancement programs to be customized for each RCSP management organization, which will counter the problems that occur following the completion of the project. Finally, the 14 elements of the three groups that form the competences of RCSP management organizations can be applied to future academic discussions related to rural community organization competence.

In this study, we developed a tool to diagnose rural community competence (Table 5). However, only the development of the tool was completed, and it was not possible to carry out the competence assessment for the actual rural community. In the future, it will be necessary to carry out the competence diagnosis through a follow-up study to verify the practical use of the competence diagnostic tool.

Table 5. The development results with the competence diagnosis tool.

\begin{tabular}{|c|c|c|}
\hline \multicolumn{2}{|c|}{ Competence Element } & Diagnosis Item \\
\hline \multirow{5}{*}{ Consensus-forming competence } & 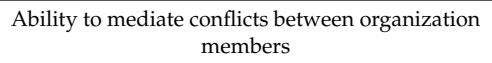 & Our organization can mediate conflicts between members. \\
\hline & $\begin{array}{c}\text { Decision-making structure between organization } \\
\text { members }\end{array}$ & $\begin{array}{l}\text { Decision-making in our organization is done by } \\
\text { sufficiently sharing opinions and publicizing the details. }\end{array}$ \\
\hline & $\begin{array}{c}\text { Consultation opportunity for organization } \\
\text { members and rural residents }\end{array}$ & $\begin{array}{l}\text { There are enough opportunities to discuss the details of the } \\
\text { project between organization members and residents. }\end{array}$ \\
\hline & Reflection of opinions of rural residents & $\begin{array}{l}\text { The opinions of rural residents are well mediated and } \\
\text { reflected in the process of the project. }\end{array}$ \\
\hline & $\begin{array}{l}\text { Awareness of organization members about } \\
\text { pending community issues }\end{array}$ & $\begin{array}{l}\text { Our organization's members sufficiently perceive the } \\
\text { pending issues of the community. }\end{array}$ \\
\hline \multirow{5}{*}{$\begin{array}{c}\text { Participatory } \\
\text { environment-creating competence }\end{array}$} & $\begin{array}{l}\text { Participation of organization members in the } \\
\text { project }\end{array}$ & $\begin{array}{c}\text { Our organization's members are actively participating in } \\
\text { the project. }\end{array}$ \\
\hline & Participation of rural residents in the project & $\begin{array}{l}\text { Our village residents are actively participating in } \\
\text { the project. }\end{array}$ \\
\hline & Social participation & $\begin{array}{c}\text { Our organization's members are interested in participating } \\
\text { in autonomous activities, volunteer work, community } \\
\text { events, etc. }\end{array}$ \\
\hline & Economic participation & $\begin{array}{c}\text { Our organization's members are interested in participating } \\
\text { in village companies, rural community businesses, } \\
\text { agricultural corporations, farming association } \\
\text { corporations, etc. }\end{array}$ \\
\hline & $\begin{array}{l}\text { Atmosphere encouraging residents from other } \\
\text { villages to participate in village affairs }\end{array}$ & $\begin{array}{l}\text { Our village welcomes residents from other villages to } \\
\text { participate in our village affairs. }\end{array}$ \\
\hline \multirow{4}{*}{$\begin{array}{l}\text { Organization-building } \\
\text { competence }\end{array}$} & $\begin{array}{l}\text { Formation of community culture through } \\
\text { the project }\end{array}$ & $\begin{array}{c}\text { Participating in the project strengthens the mutual ties } \\
\text { between residents. }\end{array}$ \\
\hline & $\begin{array}{l}\text { The project's contribution and role in resolving } \\
\text { pending issues the community }\end{array}$ & $\begin{array}{l}\text { The process of the project sufficiently helps our village to } \\
\text { resolve our pending issues. }\end{array}$ \\
\hline & Cooperation of other organizations in the village & $\begin{array}{l}\text { Other organizations, such as the village society, women's } \\
\text { society, and small communities in our village, are } \\
\text { participating in the project. }\end{array}$ \\
\hline & Activation of other organizations in the village & $\begin{array}{l}\text { Organizations such as the village society, women's society, } \\
\text { and small communities in our village, are well activated. }\end{array}$ \\
\hline
\end{tabular}

Author Contributions: Conceptualization, S.E. and M.K.; methodology, S.E. and H.K.; validation, S.E., H.K. and S.R.; formal analysis, H.K.; investigation, H.K.; data curation, S.E and M.K.; writing-original draft preparation, H.K.; writing-review and editing, S.E. and M.K.; supervision, M.K. and S.R. All authors have read and agreed to the published version of the manuscript.

Funding: This research did not receive any specific grant from funding agencies in the public, commercial, or not-for-profit sectors. 
Conflicts of Interest: The authors declare that they have no conflict of interest.

\section{References}

1. Lee, S.; Choi, J.; Seo, Y.; Kim, I. A study on the development cases and vitalization methods of rural Community in Gyeonggi-Do. Gyeonggi Research Institute. Available online: http://bit.ly/2Zg95bk (accessed on 2 September 2018).

2. Fieldhouse, P. Community shared agriculture. Agric. Hum. Values 1996, 13, 43-47. [CrossRef]

3. Song, M.; Seong, J. Evaluation of rural village development programs and suggestions for a participatory village development model. Korea Rural Economic Institute. 2004. Available online: http://bit.ly/2JXsSHD (accessed on 4 September 2019).

4. Ministry of Agriculture, Food and Rural Affairs. A Study on the Activation Plan for Rural Development Project. 2014. Available online: http://www.prism.go.kr/homepage/origin/retrieveOriginDetail.do; jsessionid=DBE2BAC436DC568ADB90D260D722B330.node02? cond_research_name=\&cond_research_ start_date=\&cond_research_end_date=\&cond_organ_id=1543000\&research_id=1543000-201500025\& pageIndex=1\&leftMenuLevel=120 (accessed on 11 May 2018).

5. Jeong, J.W.; Lim, S.B. Community Development Studies; Seoul National University Press: Seoul, Korea, 1997.

6. Chaskin, R. Building community capacity. Urban Aff. Rev. 2001, 36, 291-323. [CrossRef]

7. Shin, Y. The Influence of Community Capacity on Continuous Participation and Expansion toward Community Building; Department of Urban Design \& Landscape, The Graduate School of Urban Studies, Hanyang University: Seoul, Korea, 2012.

8. Yeo, H.; Park, S.; Kim, M. A study on the community-capacity-building of social enterprises-focused on community initiated social enterprises conducting residential environment improvement projects. J. Urban Des. Inst. Korea 2015, 16, 47-62.

9. Healey, P. Collaborative Planning; University of British Columbia Press: Vancouver, BC, Canada, 1997.

10. Chan, Y.; Lam, G.; Cheng, H. Community capacity building as a strategy of family violence prevention in a problem-stricken community: A theoretical formulation. J. Fam. Violence 2009, 24, 559-568. [CrossRef]

11. Stenning, N. Constructing Oyama Rural Community Capacity, Policy Structures and Change. Ph.D. Thesis, Ritsumeikan Asia Pacific University, Ritsumeikan, Japan, 2014.

12. Laverack, G. An identification and interpretation of the organizational aspects of community empowerment. Community Dev. J. 2001, 36, 40-52. [CrossRef]

13. Islam, M. Non-governmental organizations' role for social capital and community empowerment in community development: Experience from Bangladesh. Asian Soc. Work Policy Rev. 2014, 8, $261-274$. [CrossRef]

14. Sim, J.M. A study on community empowerment through village action planning. Urban Study 2004, 9, 162-193.

15. Kang, S. A study on the distributive characteristics and approaches of community capacity for utilization as the community welfare's asset - The case of Jeju-do. J. Korea Plan. Assoc. 2007, 42, 221-232.

16. Kim, S.; Chun, H.; Seo, Y.; Yun, Y. Measures to Enhance Social Capital in the Field of National Territorial management-Factor Analysis; (report No. 2008-24-1); Korea Research Institute for Human Settlements: Sejong-si, Korea, 2008.

17. Jänicke, M. The Political Systems Capacity for Environment Policy. In Democracy and the Environment: Problems and Prospects; Lafferty, W.M., Meadowcroft, J., Eds.; Edward Elgar Publishing: Cheltenham, UK, 1997; pp. 71-85.

18. Kim, T.; Lee, S. A study on affecting factor-construction of collaborative planning process and effect on comprehensive rural village development project. J. Korean Soc. Rural Plan. 2014, 20, 23-43. [CrossRef]

19. Seong, T.; Si, G. Research Methodology; Hakjisa: Seoul, Korea, 2014.

20. Eyduran, E.; Karakus, K.; Karakus, S.; Cengis, F. Usage of factor scores for determining relationships among body weight and some body measurements. Bulg. J. Agric. Sci. 2009, 15, 374-378.

21. Sharma, S. Applied Multivariate Techniques; John Wiley and Sons, Inc.: New York, NY, USA, 1996.

22. Noh, K. Statistical Analysis SPSS \& AMOS 21; Hanbit Publishing: Seoul, Korea, 2014.

23. Zwick, W.; Velicer, W. A Comparison of five rules for determining the number of components in data sets. Psychol. Bull. 1986, 99, 432-442. [CrossRef] 
24. Cortina, J. What is coefficient alpha? An examination of theory and applications. J. Appl. Psychol. 1993, 78, 98-104. [CrossRef]

25. Schmitt, N. Uses and abuses of coefficient alpha. Psychol. Assess. 1996, 8, 350-353. [CrossRef]

26. Nunnally, J. Psychometric Theory; Tata McGraw-Hill Ed: New York, NY, USA, 1978.

(C) 2020 by the authors. Licensee MDPI, Basel, Switzerland. This article is an open access article distributed under the terms and conditions of the Creative Commons Attribution (CC BY) license (http://creativecommons.org/licenses/by/4.0/). 